\title{
BISCUITS FROM FERMENTED ROASTED BUCKWHEAT FLOUR - PHENOLICS PROFILE AND BIOACCESSIBLE ANGIOTENSIN CONVERTING ENZYME INHIBITORY ACTIVITY
}

- Research paper -

\author{
Małgorzata WRONKOWSKA ${ }^{1}$, Joanna HONKE, Henryk ZIELIŃSKI, Wiesław WICZKOWSKI \\ Department of Chemistry and Biodynamic of Food, Division of Food Science, Institute of Animal \\ Reproduction and Food Research, Polish Academy of Sciences, 10 Tuwima Str., 10-748 Olsztyn, \\ Poland.
}

\begin{abstract}
The bioaccessible angiotensin converting enzyme (ACE) inhibitory activity of biscuits formulated from roasted common buckwheat flour after fermentation by select bacteria was studied. The same content of total phenolic compounds was found in fermented flour and in biscuits obtained from them. Generally, fermentation of flour did not changes the ACE inhibitory activity, whereas baking process significantly increased the ACE inhibitory activity of examined products. The potential bioaccessible ACE inhibitory activity from biscuits was very high. Phenolic acids such as protocatechuic, vanillic and syringic acids as well as flavonoids: kaempferol and epicatechin in the digested buckwheat biscuits have the highest impact on ACE inhibitory activity. A high significant correlations were found between $\mathrm{IC}_{50}$ and total phenolic compounds of fermented flours, biscuits before and after digestion. The data obtained in this study closely associates phenolic compounds with ACE inhibitory activity.
\end{abstract}

Keywords: buckwheat; roasting; fermentation; baking; in vitro digestion; ACE inhibition

\section{INTRODUCTION}

Food bioactive compounds, such as peptides with potent angiotensin-I converting enzyme (ACE) inhibitory activity can fulfill other roles than energetic or nutritional. This type of peptide have been separated and characterized from enzymatic hydrolysates of many foodstuffs, such as casein (Miguel et al., 2009), tuna bone protein (Je et al., 2007), soybean (Kuba et al., 2005), wheat germ (Matsui et al., 1999), lentil (Torino et al. 2013), apricot almond meal (Wang et al., 2011), and many other (Ren et al., 2014). Iwaniak et al. (2014) have been reviewed in details the foodoriginating ACE inhibitors and antihypertensive peptides which could be used for prevention in blood pressure reduction. Lacaille-Dubois et al. (2001) presented ACE inhibitory activity of flavonoids isolated from plants. It should be noted that this activity in food of plant origin results not only from flavonoids but also from other unidentified components present in the extracts.

Cardiovascular function could be modulated by flavonoids through regulation of blood pressure

Received: 19.06.2020.

Accepted in revised form: 20.08.2020
(Galleano et al., 2010), oxidative stress (Cordova et al., 2012) and inflammation (Pan et al., 2009) in the cardiovascular system. ACE plays a key physiological role in the control of blood pressure in the rennin-angiotensin system (Fujita et al., 2000). The synthetic drugs that inhibit ACE, such as captopril and enalapril (Kim et al., 2001) are commonly used for hypertension treatment. But as presented by Kumar et al. (2010) synthetic ACE inhibitors can have adverse side effects such as cough, taste disturbances, skin rashes or angioneurotic edema.

Giménez-Bastida and Zieliński (2015) showed that consumption of buckwheat is associated with differentiated activities such as: antioxidant, hypotensive, antispasmodic, hypocholesterolemic, hypoglycemic, anticancer, and anti-inflammatory anti-glycation activities. Higasa et al. (2011) showed that buckwheat have high levels of angiotensin I-converting enzyme (ACE)-inhibitory activity. The greatest ACE inhibitory activity $\left(\mathrm{IC}_{50}\right.$ $=30 \mu \mathrm{g} / \mathrm{mL}$ ) was found for the extracts of buckwheat hulls (Tsai et al., 2012). These finding suggest the impact of polyphenols on ACE inhibitory activity, because hull is a rich source of

${ }^{1}$ Corresponding author. E-Mail address: m.wronkowska@ pan.olsztyn.pl 
flavonoids and phenolics acids (Zielińska et al., 2013). Recently it was found that lentil polyphenol extract prevents angiotensin II-induced hypertension, vascular remodeling and perivascular fibrosis (Yao et al. 2012). As presented Jakobek (2015) health-promoting features of the polyphenols is due to the fact that it could be solubilized in digestive fluids, then absorbed and metabolized in gastrointestinal tract. It has been reported that thermal processing of cereals may positively or negatively affect the content of polyphenols in cereal and pseudocereals bakery products (Giménez-Bastida et al., 2015). Spínola et al. (2018) showed for Madeira sorrel, a wild leafy-vegetable, that in vitro digestion model could be used to predict the bioavailability of phenols, and these types of analysis is simpler and easier to perform than the animal model.

The fermentation of cereals or pseudo-cereals is related to lactic acid bacteria (Charalampopoulos et al., 2009; Muller et al., 2001). The development of flavour, enhancement of the nutritional value and shelf life, and removing toxic or antinutritional factors of obtained products could be indicated as those properties associated with cereal fermentation (Coda et al., 2014). As presented by Baráth et al. (2004) that effects are connected with the production of organic acids (lactic and acetic) and $\mathrm{pH}$ lowering. Zieliński et al. (2017) showed that fermentation of buckwheat flour by $L$. plantarum could be used for the production of functional products.

The aim of this study was to investigate the potential bioaccessible ACE inhibitory activity under the influence of the applied process: fermentation, baking and in vitro digestion of products obtained from roasted buckwheat flour fermented by selected bacteria. The contribution of total phenolic compounds (TPC) to the ACE inhibitory activity of roasted buckwheat fermented flours and obtained biscuits before and after in vitro digestion were also investigated.

al. (2009) described the roasting process used in the industry in previous publication. Wronkowska et al. (2018) and Zielinski et al. (2019) presented the processes used for flour pre-treatment, the origin of selected bacteria used, and the fermentation process. Freeze-drying was used for dehydration process

\section{Biscuits from roasted buckwheat fermented flours - baking process}

The AACC 10-52 method (2000) with the modification proposed by Hidalgo and Brandolini (2011) was used for biscuit dough preparation. In the recipe used in our study sugar, shortening and non-fat dry milk have not been applied. All ingredients were mixed for 3 minutes (Kitchen Aid, St. Joseph, MI, USA), then the dough was cut with a square cookie cutter $(60 \mathrm{~mm})$. The biscuits were baked in electric oven (Sveba Dahlen AB, Fristad, Sweden) at temperature $220^{\circ} \mathrm{C}$ for $30 \mathrm{~min}$. The obtained biscuits were freeze-dried, milled and stored in a refrigerator until analysis. (E2O), hydrochloric acid (HCl) and sodium hydroxide $(\mathrm{NaOH})$. The Mili-Q-system (Milipore, Bedford, USA) was used for water purification.

\section{Roasted buckwheat flours - fermentation process}

The roasted common buckwheat groats (Fagopyrum esculentum Moench) (Melvit S.A., Kruki, Poland) were milled into flour and then were called roasted buckwheat flour. Zieliński et

\section{Biscuits from roasted buckwheat fermented flours - in vitro digestion}

The biscuits were subjected to successive in vitro digestion according Delgado-Andrade et al. (2010). In first step: samples were incubated with $\alpha$-amylase solution $\left(37^{\circ} \mathrm{C} / 30 \mathrm{~min}\right.$., $\left.\mathrm{pH} 7.0\right)$. In second step: after the reduction of the $\mathrm{pH}$ to 2.0 
samples were incubated with pepsin solution $\left(37^{\circ} \mathrm{C} / 120 \mathrm{~min}.\right)$. In the last step: the $\mathrm{pH}$ was adjusted to 6.0, and a mixture of pancreatin and bile salts extract was added. Then the samples were incubated $120 \mathrm{~min}$. at $37^{\circ} \mathrm{C}$ after the $\mathrm{pH}$ adjusted to 7.5. For inactivating of the enzymes the heating at $100^{\circ} \mathrm{C}$ for 4 minutes was used, then samples were centrifuged. Obtained supernatant were stored at $-20^{\circ} \mathrm{C}$ for the evaluation of TPC and bioaccessible ACE inhibitory activity.

The bioaccessibility index (BI) were determined for illustration of the bioaccessible ACE inhibitory activity in vitro:

$\mathrm{BI}=\left(1 / \mathrm{IC}_{50}\right)_{\mathrm{GD}} /\left(1 / \mathrm{IC}_{50}\right)_{\mathrm{BB}}$;

where $\left(\mathrm{IC}_{50}\right)_{\mathrm{GD}}$ is the $\mathrm{ACE}$ inhibitory activity after in vitro digestion $(\mathrm{GD})$ and $\left(\mathrm{IC}_{50}\right)_{\mathrm{BB}}$ is the $\mathrm{ACE}$ inhibitory activity of buckwheat biscuits (BB). BI value higher then one indicates high bioaccessibility and BI value lower than one indicates low bioaccessibility.

Roasted buckwheat fermented flours and biscuits before and after in vitro digestion determination of TPC

Analysed samples $(100 \mathrm{mg})$ were extracted with $80 \% \mathrm{MeOH}, \quad$ then were vortexed/sonicated/vortexed, and centrifuged. This procedure was repeated 5 times, the final extract concentration was $20 \mathrm{mg} / \mathrm{mL}$. Then extracts as well as supernatants obtained after in vitro digestion were mixed with the Folin-Ciocalteu reagent, left for $25 \mathrm{~min}$ at room temperature, and centrifuged. Spectrophotometer (model A UV-160 1PC, Shimadzu, Japan) was used for the absorbance determination at $725 \mathrm{~nm}$, results were expressed as milligrams of gallic acid equivalents (GAE) per gram of dry matter (d.m.) sample (Zieliński et al., 2017).

Extraction and isolation of the main phenolic compounds from roasted buckwheat fermented flour and biscuits before and after in vitro digestion

Freeze-dried samples were extracted with $80 \%$ methanol according Wiczkowski et al. (2016) assay. Free forms of polyphenols were isolated by diethyl ether, but conjugated forms (esters and glycosides) samples were initially hydrolysed with $\mathrm{NaOH}$ and $\mathrm{HCl}$. After each hydrolysis, the extraction process was conducted in triplicates, the collected ether extracts were evaporated to dryness. For the analysis of profile and content of phenolic acids and flavonoids the system HPLCMS/MS involving an HALO column was applied (Wiczkowski et al., 2016).

\section{Angiotensin-I-converting enzyme (ACE) inhibitory assay}

Freeze-dried samples $(300 \mathrm{mg})$ were 5-times extracted with $70 \%$ aqueous methanol. Before assay evaporated extract were dissolved in deionized water, but the supernatants obtained after in vitro digestion of biscuits were used directly. Each sample was diluted to various concentrations and then used for the evaluation of the ACE inhibitory activities (expressed as $\mathrm{IC}_{50}$ ).

Method proposed by Sentandreu and Toldra (2006) was used for determination of ACE inhibitory activities. Exactly $50 \mu \mathrm{L}$ of ACE working solution $(7.5 \mathrm{mg} / \mathrm{mL}$ in $150 \mathrm{mM}$ Tris-base buffer, $\mathrm{pH}$ 8.3) was added to each microliter-plate well, then adjusted to $100 \mu \mathrm{L}$ by adding either deionized water (control) or samples in the inhibition studies. The enzyme reaction was initiated by the addition of $200 \mu \mathrm{L}$ of substrate working solution of Abz-Gly-Phe $\left(\mathrm{NO}_{2}\right)$-pro (in tris-base buffer, $\mathrm{pH} 8.3$ ), immediately mixed and incubated at $37^{\circ} \mathrm{C}$. The generated fluorescence was measured immediately after mixing $(0 \mathrm{~min})$ and then after $30 \mathrm{~min}$ of reaction using multiscan microplate fluorometer at an excitation of $365 \mathrm{~nm}$ and an emission of $405 \mathrm{~nm}$. To calculate the \% of inhibition of ACE, the following equation was used:

$$
\begin{aligned}
& \quad \text { Relative ACE activity } \%=100- \\
& \text { - } \quad\left(\Delta \mathrm{RFU}_{\text {sample }} * 100 / \Delta \mathrm{RFU}_{\text {negative control }}\right)
\end{aligned}
$$

where $\Delta R F U=R F U_{\text {at time } 30}-R_{F U}$ at time 0 .

\section{Statistical analysis}

The mean values and the standard deviation of three independent measurements were presented as the illustration of the obtained results. Student's ttest for less numerous groups $(\mathrm{P}<0.05)$ was used for determination of the differences in the $\mathrm{IC}_{50}$ or TPC in control sample compared to other analysed samples. All data were analysed using one-way analysis of variance (ANOVA) with Fisher's Least Significant Difference test $(\mathrm{P}<0.05)$. The Pearson correlation coefficient was used for the correlation analysis $(\mathrm{P}<0.05)$. All analysis were performed in STATISTICA for Windows (StatSoft Inc., Tulsa, USA, 2001). 


\section{RESULTS AND DISCUSSION}

Effect of fermentation on ACE inhibitory activity of roasted buckwheat flours

The $\mathrm{IC}_{50}$ of control, non fermented roasted buckwheat flours, was $60.86 \mathrm{mg} \mathrm{mL}^{-1}$ (Table 1). According to definition proposed by Mojica et al. (2015) the lower $\mathrm{IC}_{50}$, the higher ACE inhibitory activity of analysed product. Compared to control sample, non fermented roasted buckwheat flour, the significantly higher ACE inhibitory activity was noticed for roasted flours fermented by two Lactobacillus strains: L. delbrucki subsp. bulgaricus 151 and L. plantarum W42 (Table 1). For eight bacteria strains, the ACE inhibitory activity were at a similar level as was provided for control sample, whereas for four bacteria a decrease in ACE inhibitory activity was noticed $(\mathrm{P}<0.05)$. Summing up the results, it should be stated that ACE inhibitory activity did not change generally under the influence of fermentation by selected bacteria.

Currently it is noted increased interest in natural sources of ACE inhibitory peptides due to the fact that they are considered to come from safe sources (Rui et al., 2015). The ACE inhibitory effect may depend on the plant material used and also microorganisms used as it was showed by: Pyo and Lee (2007), Torino et al. (2013), and Juan et al. (2010). These authors demonstrated the ACE inhibitory activity of Monascus fermented soybean, Lactobacillus plantarum fermented lentil, and Bacillus spp. fermented black soybeans, with $\mathrm{IC}_{50}$ of $0.29 ; 0.20$ and $1.81-2.35 \mathrm{mg} / \mathrm{mL}$, respectively. Navy bean and chickpea do not showed the ACE inhibitory activity, but fermented products obtained from them exhibit this property (Rui et al., 2015; Xiao et al., 2015).

Effect of baking on ACE inhibitory activity of biscuits obtained from roasted buckwheat fermented flour

Table 1 showed the results of ACE inhibition after the baking process $\left(220^{\circ} \mathrm{C} / 30 \mathrm{~min}\right)$, control biscuits from not fermented roasted buckwheat flour get $\mathrm{IC}_{50}$ values of $81.31 \mathrm{mg} \mathrm{mL}^{-1}$. Generally, significantly increase of the ACE inhibitory activity under the influence of baking process was observed. For eleven biscuits significant decrease of $\mathrm{IC}_{50}$ values compared to control biscuit was found (Table 1). While Mojica et al. (2015) did not found differences of $\mathrm{IC}_{50}$ values of raw and precooked bean, and those authors suggested that ACE inhibitory potential of common bean was not affected by processing.

Effect of in vitro digestion on ACE inhibitory activity of biscuits obtained from roasted buckwheat fermented flour

In Table 1 were presented the results of ACE inhibitory activity of supernatant obtained after in vitro digestion of buckwheat biscuits. All analysed supernatants showed significantly higher ACE inhibitory activity (e.g. lower $\mathrm{IC}_{50}$ values) compared to flours and biscuits. The $\mathrm{IC}_{50}$ values of supernatant obtained after digestion of control biscuits was $3.07 \mathrm{mg} \mathrm{mL} \mathrm{m}^{-1}$. Only for sample fermented by $L$. plantarum IB and $L$. acidophilus $\mathrm{V}$ significant decrease of $\mathrm{IC}_{50}$ compared to digested control sample was observed.

Table 1. The $\mathrm{IC}_{50}$ of samples obtained from roasted buckwheat $\left(\mathrm{mg} \mathrm{mL}^{-1}\right)$

\begin{tabular}{llccc}
\hline No & Strain/sample & Flour & Biscuits & Digested biscuits \\
\hline 1 & Control & $60.86 \pm 1.46 \mathrm{~b}$ & $81.31 \pm 4.76 \mathrm{a}$ & $3.07 \pm 0.04 \mathrm{c}$ \\
\hline 2 & L. plantarum IB & $57.15 \pm 2.76 \mathrm{~b}$ & $70.86 \pm 3.45 * \mathrm{a}$ & $2.71 \pm 0.07 * \mathrm{c}$ \\
3 & L. plantarum W42 & $54.97 \pm 0.76 * \mathrm{~b}$ & $75.91 \pm 7.38 \mathrm{a}$ & $3.25 \pm 0.05 * \mathrm{c}$ \\
4 & L. delbrucki subsp. bulgaricus 151 & $43.63 \pm 2.11 * \mathrm{~b}$ & $60.24 \pm 4.20 * \mathrm{a}$ & $3.16 \pm 0.32 \mathrm{c}$ \\
5 & L. casei Lcy & $81.30 \pm 2.58 * \mathrm{a}$ & $36.92 \pm 6.43 * \mathrm{~b}$ & $3.59 \pm 0.20 * \mathrm{c}$ \\
6 & Streptococcus thermophilus MK-10 & $68.76 \pm 2.64 \mathrm{~b}$ & $109.50 \pm 7.93 * \mathrm{a}$ & $3.21 \pm 0.29 \mathrm{c}$ \\
7 & L. acidophilus La5 & $79.60 \pm 1.34 * \mathrm{a}$ & $67.50 \pm 5.12 * \mathrm{~b}$ & $3.35 \pm 0.13 * \mathrm{c}$ \\
8 & L. acidophilus V & $77.31 \pm 0.49 * \mathrm{a}$ & $61.16 \pm 6.47 * \mathrm{~b}$ & $2.80 \pm 0.08 * \mathrm{c}$ \\
9 & L. acidophilus 145 & $58.48 \pm 2.31 \mathrm{~b}$ & $110.98 \pm 1.15 * \mathrm{a}$ & $4.14 \pm 0.40 * \mathrm{c}$ \\
10 & L. casei $2 \mathrm{~K}$ & $67.04 \pm 3.09 \mathrm{a}$ & $21.77 \pm 3.54 * \mathrm{~b}$ & $3.79 \pm 0.53 \mathrm{c}$ \\
11 & L. delbrucki subsp. bulgaricus $\mathrm{K}$ & $66.99 \pm 3.65 \mathrm{a}$ & $38.16 \pm 4.61 * \mathrm{~b}$ & $3.75 \pm 0.33 * \mathrm{c}$ \\
12 & L. rhamnosus GG & $68.18 \pm 0.52 * \mathrm{~b}$ & $73.41 \pm 0.77 * \mathrm{a}$ & $3.48 \pm 0.32 \mathrm{c}$ \\
13 & L. rhamnosus $8 / 4$ & $63.41 \pm 3.52 \mathrm{a}$ & $66.71 \pm 3.52 * \mathrm{a}$ & $3.60 \pm 0.03 * \mathrm{~b}$ \\
14 & L. rhamnosus K & $61.74 \pm 3.84 \mathrm{a}$ & $56.99 \pm 1.82 * \mathrm{a}$ & $3.30 \pm 0.18 \mathrm{~b}$ \\
15 & L. salivarius AWH & $69.41 \pm 3.10 \mathrm{a}$ & $54.32 \pm 3.53 * \mathrm{~b}$ & $2.96 \pm 0.24 \mathrm{c}$ \\
\hline
\end{tabular}

Data presented as mean \pm standard deviation $(n=3)$. *means in each column followed by asterisk are significantly different at $\mathrm{P}<0.05$ based on the Student's t-test for less numerous groups. Different letters (a-c) within the same row indicate statistically significantly different at $\mathrm{P}<0.05$ in LSD Fisher test. 
The bioaccessible ACE inhibitory activity of biscuits obtained from roasted buckwheat fermented flour

The ACE inhibitory activity of the digested biscuits were significantly higher compared to no digested biscuits (Table 1). In our study, for the digested biscuits the BI values from 5.7 to 34.1 (Figure 1) were noted, and the highest value was found for Streptococcus thermophilus MK-10 (34.1), followed by $L$. acidophilus 145 and $L$. rhamnosus GG, whereas BI value for digested biscuits made of non-fermented roasted buckwheat flour was 26.5 (Figure 1). Generally, high potential bioaccessibility of ACE inhibitory activity from experimental biscuits was observed in this study. Gawlik-Dziki et al. (2016) showed that BI could be used for coffee and coconut as useful parameter to study the phenolics bioaccessibility. For tartary buckwheat $\mathrm{Li}$ at al. (2002) showed that pepsin hydrolysis has not effect on increased the ACE inhibitory action. But these authors showed that when combined action of pepsin and trypsin/chymotrypsin was applied the significant increase in the inhibitory activity was noted. Kawakami et al. (1995) found that enzymatic hydrolysis of buckwheat proteins positively effects on the production of ACE inhibitors, and those could suggest that gastrointestinal digestion support the ability to inhibit ACE.

Effect of fermentation, baking and in vitro digestion on the content of TPC of analysed samples

Generally, significant increase in TPC in roasted buckwheat flour fermented by selected bacteria strains was observed as compared to the non- fermented roasted flour (Table 2). Moreover, baking process did not change significantly the TPC content and similarly like for flours a slight increase of TPC in biscuits was noticed. Significantly higher TPC content was found in samples obtained after digestion of examined biscuits compared to the fermented flours or biscuits before digestion. But compared to digested control biscuits there were not significantly different in TPC, except for three type of the biscuits obtained from flour fermented by: L. delbrucki subsp. bulgaricus 151, S. thermophilus MK-10 and L. rhamnosus GG (Table 2).

As it was showed by other authors the increase of TPC content was observed during the solid-state fermentation of oat by fungus Monascus anka GIM 3.592 (Bei et al., 2020) and lentils by Aspergillus oryzae and A. niger (Alves Magro et al., 2019).

The average levels of main phenolic compounds from analysed samples - profile and content In all analysed samples ten phenolic acids and eight flavonoids were found (Table 3 and 4). Phenolic acids included derivatives of hydroxycinnamic and hydroxybenzoic acids: chlorogenic, p-coumaric, sinapic, ferulic, tcinnamic, syringic, vanillic, isovanillic, protocatechuic and caffeic acids. The average (calculated for all analysed samples) level of detected phenolic acids is shown in Table 3. Isovanillic acid was identified only in biscuits before and after digestion.

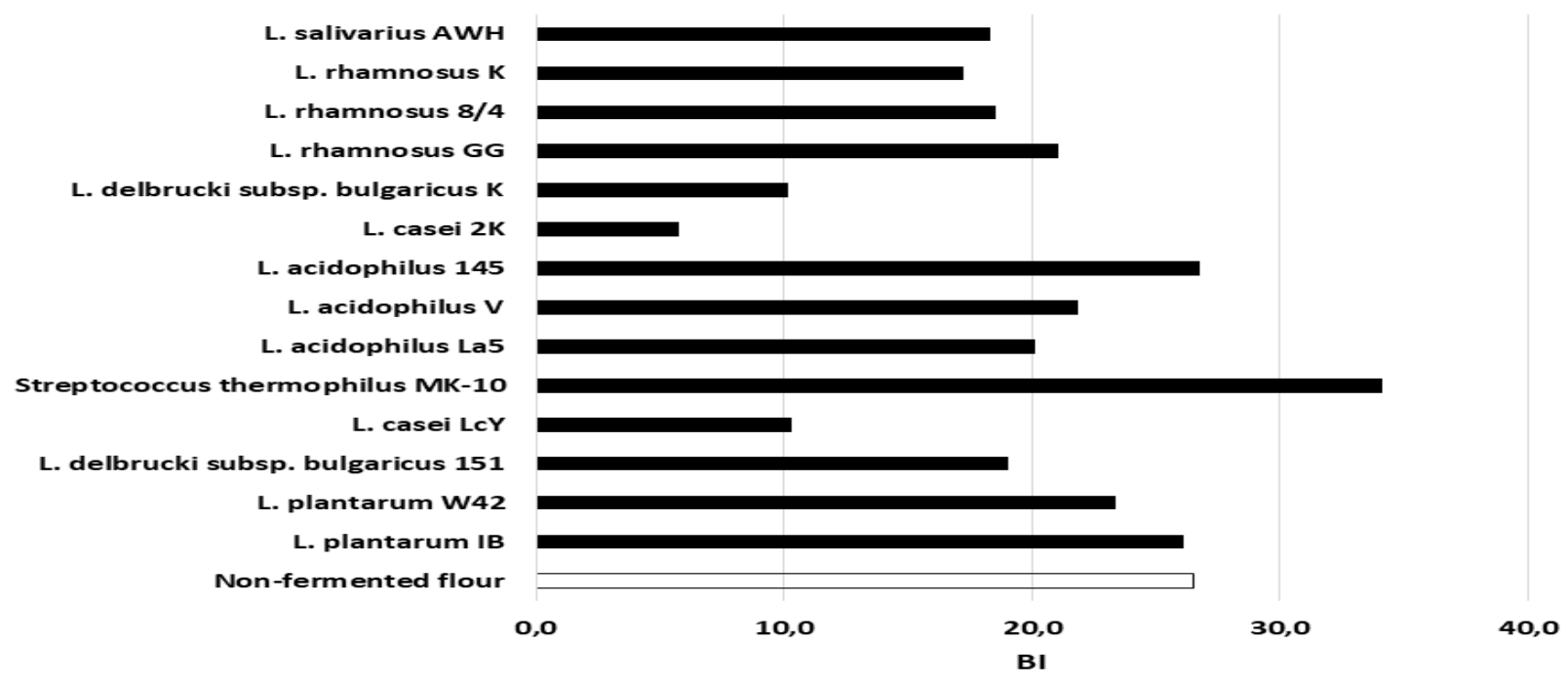

Figure 1. The bioaccessibility index (BI) of biscuits formulated from roasted buckwheat fermented flours 
Table 2. The content of total phenolic compounds (TPC) in samples obtained from roasted buckwheat (mg GAE/g d.m.).

\begin{tabular}{llccc}
\hline No & Strain/sample & Flour & Biscuits & Digested biscuits \\
\hline 1 & Control & $0.89 \pm 0.07 \mathrm{~b}$ & $0.80 \pm 0.05 \mathrm{~b}$ & $5.22 \pm 0.14 \mathrm{a}$ \\
\hline 2 & L. plantarum IB & $1.16 \pm 0.07 * \mathrm{~b}$ & $1.23 \pm 0.07 * \mathrm{~b}$ & $4.83 \pm 0.18 * \mathrm{a}$ \\
3 & L. plantarum W42 & $1.14 \pm 0.06 * \mathrm{~b}$ & $0.96 \pm 0.03 * \mathrm{~b}$ & $4.94 \pm 0.29 \mathrm{a}$ \\
4 & L. delbrucki subsp. bulgaricus 151 & $1.00 \pm 0.16 \mathrm{~b}$ & $0.90 \pm 0.01 * \mathrm{~b}$ & $5.67 \pm 0.24 * \mathrm{a}$ \\
5 & L. casei Lcy & $1.02 \pm 0.15 \mathrm{~b}$ & $1.03 \pm 0.04 * \mathrm{~b}$ & $5.24 \pm 0.24 \mathrm{a}$ \\
6 & Streptococcus thermophilus MK-10 & $1.11 \pm 0.05 * \mathrm{~b}$ & $0.83 \pm 0.06 \mathrm{c}$ & $6.02 \pm 0.14 * \mathrm{a}$ \\
7 & L. acidophilus La5 & $1.25 \pm 0.16 * \mathrm{~b}$ & $1.18 \pm 0.03 * \mathrm{~b}$ & $5.42 \pm 0.38 \mathrm{a}$ \\
8 & L. acidophilus V & $1.25 \pm 0.09 * \mathrm{~b}$ & $1.07 \pm 0.06 * \mathrm{~b}$ & $5.63 \pm 0.27 \mathrm{a}$ \\
9 & L. acidophilus 145 & $1.21 \pm 0.06 * \mathrm{~b}$ & $0.82 \pm 0.01 \mathrm{c}$ & $4.94 \pm 0.09 * \mathrm{a}$ \\
10 & L. casei 2K & $0.93 \pm 0.31 \mathrm{~b}$ & $0.74 \pm 0.03 \mathrm{~b}$ & $4.80 \pm 0.09 * \mathrm{a}$ \\
11 & L. delbrucki subsp. bulgaricus $\mathrm{K}$ & $0.96 \pm 0.10 \mathrm{~b}$ & $0.83 \pm 0.04 \mathrm{~b}$ & $4.99 \pm 0.13 \mathrm{a}$ \\
12 & L. rhamnosus GG & $1.16 \pm 0.14 * \mathrm{~b}$ & $0.91 \pm 0.01 * \mathrm{~b}$ & $5.72 \pm 0.24 * \mathrm{a}$ \\
13 & L. rhamnosus $8 / 4$ & $0.95 \pm 0.04 \mathrm{~b}$ & $0.69 \pm 0.02 * \mathrm{c}$ & $5.09 \pm 0.24 \mathrm{a}$ \\
14 & L. rhamnosus K & $0.88 \pm 0.16 \mathrm{~b}$ & $0.78 \pm 0.01 \mathrm{~b}$ & $4.47 \pm 0.19 * \mathrm{a}$ \\
15 & L. salivarius AWH & $0.87 \pm 0.14 \mathrm{~b}$ & $0.84 \pm 0.01 \mathrm{~b}$ & $4.37 \pm 0.12 * \mathrm{a}$ \\
\hline
\end{tabular}

Data presented as mean \pm standard deviation $(\mathrm{n}=3)$. *means in each column followed by asterisk are significantly different at $\mathrm{P}<0.05$ based on the Student's t-test for less numerous groups. Different letters (a-c) within the same row indicate statistically significantly different at $\mathrm{P}<0.05$ in LSD Fisher test.

In non-fermented and fermented roasted buckwheat flours: caffeic, vanillic and ferulic acids were in the highest concentration among average content of other identified phenolic acids (Table 3). Concentration of individual phenolic acids in fermented roasted buckwheat flours was differentiated. The average content of t-cinnamic acid was almost $50 \%$ lower in fermented flour compared to non-fermented ones. Baking process caused a reduction of content of phenolic acids with exception of syringic and protocatechuic acids (Table 3). Abdel-Aal and Rabalski (2013) observed for wholegrain bakery products that thermal process influenced on the content and profile of phenolic acids. Generally, after digestion the total average concentration of phenolic acids increased as compared to non-digested biscuits.
The highest increase was noticed for caffeic and sinapic acids, 8 and 5-times compared to their content in biscuits before digestion, respectively. Only for syringic acid the decrease of its level was observed after digestion.

In this study flavonoids in analysed samples included: luteolin, kaempherol, quercetin, rutin, vitexin, apigenin, orientin and epicatechin and their average levels is shown in Table 4. In nonfermented and fermented roasted buckwheat flours the highest average concentration was observed for rutin and epicatechin. Generally, fermentation process did not change the content of flavonoids compared to unfermented roasted buckwheat flour. Only concentration of rutin and epicatechin decrease was observed.

Table 3. Average levels of phenolic acids $(\mu \mathrm{g} / \mathrm{mL})$ in samples obtained from roasted buckwheat

\begin{tabular}{lcccc}
\hline Sample & Non-fermented flour & Fermented flour & Biscuits & Digested biscuits \\
\hline Chlorogenic & $0.07 \pm 0.01$ & $0.05 \pm 0.02$ & $0.08 \pm 0.06$ & $0.10 \pm 0.01$ \\
p-Coumaric & $13.5 \pm 0.1$ & $19.3 \pm 8.5$ & $13.6 \pm 8.3$ & $13.1 \pm 3.4$ \\
Sinapic & $8.7 \pm 0.6$ & $6.1 \pm 2.2$ & $2.1 \pm 0.7$ & $10.5 \pm 1.5$ \\
Ferulic & $70.5 \pm 2.4$ & $59.3 \pm 7.9$ & $2.6 \pm 0.4$ & $4.8 \pm 0.9$ \\
t-Cinnamic & $10.0 \pm 0.2$ & $5.8 \pm 3.6$ & $5.4 \pm 2.1$ & $11.7 \pm 3.2$ \\
Syringic & $24.7 \pm 0.7$ & $30.4 \pm 5.1$ & $114.8 \pm 23.5$ & $68.2 \pm 8.3$ \\
Vanillic & $68.6 \pm 1.5$ & $65.7 \pm 10.4$ & $50.9 \pm 16.6$ & $86.6 \pm 15.1$ \\
Isovanillic & nd & nd & $4.2 \pm 3.1$ & $13.2 \pm 3.4$ \\
Protocatechuic & $25.2 \pm 0.3$ & $25.2 \pm 6.5$ & $38.3 \pm 10.1$ & $128.2 \pm 31.1$ \\
Caffeic & $89.3 \pm 3.8$ & $61.5 \pm 36.6$ & $2.0 \pm 1.0$ & $17.7 \pm 6.9$ \\
\hline Total & 310.6 & 273.4 & 234.0 & 354.1 \\
\hline
\end{tabular}


Table 4. Average levels of flavonoids $(\mu \mathrm{g} / \mathrm{mL})$ in samples obtained from roasted buckwheat.

\begin{tabular}{lcccc}
\hline Sample & Non-fermented flour & Fermented flour & Biscuits & Digested biscuits \\
\hline Luteolin & $0.24 \pm 0.01$ & $0.30 \pm 0.08$ & $0.18 \pm 0.04$ & $0.35 \pm 0.05$ \\
Kaempferol & $0.78 \pm 0.01$ & $1.00 \pm 0.30$ & $4.6 \pm 1.4$ & $18.3 \pm 2.1$ \\
Quercetin & $3.8 \pm 0.1$ & $3.9 \pm 1.3$ & $3.3 \pm 1.8$ & $5.8 \pm 1.8$ \\
Rutin & $172.5 \pm 0.3$ & $139.9 \pm 25.1$ & $65.0 \pm 8.6$ & $2.1 \pm 0.5$ \\
Vitexin & $22.4 \pm 1.2$ & $16.4 \pm 2.1$ & $12.3 \pm 2.7$ & $6.1 \pm 0.8$ \\
Apigenin & $0.70 \pm 0.05$ & $0.5 \pm 0.1$ & $1.3 \pm 0.7$ & $1.0 \pm 0.1$ \\
Orientin & $14.2 \pm 0.5$ & $9.7 \pm 2.3$ & $6.2 \pm 1.9$ & $2.2 \pm 0.4$ \\
Epicatechin & $138.5 \pm 1.6$ & $96.6 \pm 33.0$ & $11.9 \pm 11.3$ & $17.7 \pm 3.9$ \\
\hline Total & 353.1 & 268.3 & 104.8 & 53.5 \\
\hline
\end{tabular}

Baking process used $\left(220^{\circ} \mathrm{C}, 30 \mathrm{~min}\right)$ causes a decrease in the content of investigated flavonoids, but most noticeable again in the case of rutin and epicatechin (Table 4). After in vitro digestion the average level of rutin, apigenin and orientin were further reduced, whereas the average concentration of kaempherol, quercetin, luteolin and epicatechin was increased. Generally, after digestion the total average concentration of flavonoids was reduced twice as compared to non-digested biscuits (Table 4). The highest decrease was found for rutin, the main buckwheat flavonoid.

Park et al. (2007) observed increments of phenol and flavonoids after the fermentation of soybean meal with different microorganisms. Broccoli coproducts, which was used as a cracers ingredient, increase of TPC content and also after simulated gastrointestinal digestion the amount of phenolic and antioxidant compounds was higher as found by Lafarga et al. (2019).

Correlation study focused on the contribution of TPC, phenolic acids and flavonoids to the ACE inhibitory activity of analysed samples

High significant correlation $(\mathrm{r}=0.79)$ was found between $\mathrm{IC}_{50}$ and TPC of non fermented and fermented flours, biscuits before and after digestion (Table 5). Almost for all analysed phenolic acids the correlation coefficient were ranged from $\mathrm{r}=0.14$ (syringic acid) to $\mathrm{r}=0.99$ (protocatechuic acid). These evidences clearly indicate for the contribution of phenolic compounds in ACE inhibitory activity of the samples obtained from roasted buckwheat fermented by selected bacteria strains.

The opposite situation was noticed for flavonoids, the correlation coefficients $r=-0.67$ were found between $\mathrm{IC}_{50}$ and TPC, total flavonoids of nonfermented and fermented flour, biscuits before and after digestion (Table 5). But it should be noted that correlation coefficients found between $\mathrm{IC}_{50}$ and selected flavonoids, such as luteolin, kaempferol and quercetin were $0.75 ; 0.98$ and 0.97 , respectively.

Table 5. The values of the Pearson correlation coefficient between $1 / \mathrm{IC}_{50}$ and $\mathrm{TPC}$, phenolic acids and flavonoids of non-fermented and fermented roasted buckwheat flours, biscuit before and after in vitro digestion $(\mathrm{P}<0.05)$

\begin{tabular}{lc}
\hline $\begin{array}{l}\text { Bioactive } \\
\text { compounds/samples }\end{array}$ & $\begin{array}{c}\text { Samples based on roasted } \\
\text { buckwheat flour* }\end{array}$ \\
\hline Total phenolic acids & 0.79 \\
\hline Chlorogenic & 0.80 \\
$p$-Coumaric & -0.40 \\
Sinapic & 0.67 \\
Ferulic & -0.55 \\
$t$-Cinnamic & 0.75 \\
Syringic & 0.14 \\
Vanillic & 0.85 \\
Isovanillic & 0.95 \\
Protocatechuic & 0.99 \\
Caffeic & -0.41 \\
\hline Total flavonoids & -0.67 \\
\hline Luteolin & 0.75 \\
Kaempferol & 0.98 \\
Quercetin & 0.97 \\
Rutin & -0.81 \\
Vitexin & -0.79 \\
Apigenin & 0.24 \\
Orientin & -0.77 \\
Epicatechin & -0.52 \\
\hline
\end{tabular}

*non-fermented flour; fermented flours; biscuit and sample after digestion 


\section{CONCLUSIONS}

Generally, the fermentation by selected bacteria of roasted buckwheat flour did not change of ACE inhibitory activity, but was strains dependent. Whereas, baking and digestion significantly increase those properties of biscuits prepared from fermented roasted buckwheat flour. A high significant correlations were found between $\mathrm{IC}_{50}$ and TPC of fermented flour, biscuit before and after digestion, what should indicate contribution of phenolic compounds in ACE inhibitory activity.

\section{ACKNOWLEDGEMENTS}

This work was supported by grant No 2014/15/B/NZ9/04461 from the National Science Centre, Poland. The authors thanks MSc Natalia BĄCZEK for in vitro digestion of analysed samples.

\section{REFERENCES}

1. AACC International (2000). Baking quality of cookie flour - micro method. Method 10-52, Approved Methods of the American Association of Cereal Chemists, $10^{\text {th }}$ ed. AACC International, St. Paul, MN, USA

2. Abdel-Aal, E-S.M. \& Rabalski, I. (2013). Effect of baking on free and bound phenoli acids in wholegrain bakery products. J. Cereal Sci., 57, 312-318. DOI: 10.1016/j.jcs.2012.12.001

3. Magro, A.E.A., Carvalho Silva, L., Boscariol Rasera, G. \& Soares de Castro, R.J. (2019). Solid-state fermentation as an efficient strategy for the biotransformation of lentils: enhancing their antioxidant and antidiabetic potentials. Bioresources and Bioprocessing, 6, 38. DOI: 10.1186/s40643-019-0273-5

4. Baráth, Á., Halász, A., Németh, E. \& Zalán, Z. (2004). Selection of LAB strains for fermented red beet juice production. Eur. Food Res. Technol., 218(2), 184-187. DOI: 10.1007/s00217-003-0832-y

5. Bei, Q., Wu, Z. \& Chen, G. (2020). Dynamic changes in the phenolic composition and antioxidant activity of oats during simultaneous hydrolysis and fermentation. Food Chem., 305, 125269. DOI: 10.1016/j.foodchem.2019.125269

6. Charalampopoulos, D., Vazquez, J.A. \& Pandiella, S.S. (2009). Modelling and validation of Lactobacillus plantarum fermentations in cereal-based media with different sugar concentrations and buffering capacities. Biochem. Engine. J., 44(2), 96-105. DOI: 10.1016/j.bej.2008.11.004

7. Coda, R., Di Cagno, R., Gobbetti, M. \& Rizzello, C.G. (2014). Sourdough lactic acid bacteria: exploration of nonwheat cereal-based fermentation. Food Microbiol., 37, 51-58. DOI: 10.1016/j.fm.2013.06.018

8. Cordova, A.C., Sumpio, B.J. \& Sumpio, B.E. (2012). Perfecting the plate: Adding cardioprotective compounds to the diet. J. Am. College Surgeons, 214, 97-114. DOI: 10.1016/j.jamcollsurg.2011.09.023

9. Delgado-Andrade, C., Conde-Aguilera, J.A., Haro, A., De La Cueva, S.P. \& Rufián-Henares, J.A. (2010). A combined procedure to evaluate the global antioxidant response of bread. J. Cereal Sci., 56(2), 239-246. DOI: 10.1016/j.jcs.2010.05.013

10. Fujita, H., Yokoyama, K. \& Yoshikawa, M. (2000). Classification and antihypertensive activity of angiotensin I-converting enzyme inhibitory peptides derived from food proteins. J. Food Sci., 65, 564569. DOI: $10.1111 /$ j.1365-2621.2000.tb16049.x

11. Galleano, M., Pechanova, O. \& Fraga, C.G. (2010). Hypertension, nitric oxide, oxidants, and dietary polyphenols. Curr. Pharm. Biotechno., 11, 837-848. DOI: 10.2174/138920110793262114

12. Gawlik-Dziki, U., Durak, A., Jamioł, M. \& Świeca, M.I. (2016). Interactions between antiradical and anti-inflammatory compounds from coffee and coconut affected by gastrointestinal digestion - in In vitro study. LWT - Food Sci. Technol., 69, 506-514. DOI: 10.1016/j.lwt.2016.01.076

13. Giménez-Bastida, J.A. \& Zieliński, H. (2015). Buckwheat as a functional food and its effects on health. J. Agr. Food Chem., 63(36), 7896-7913. DOI: 10.1021/acs.jafc.5b02498

14. Giménez-Bastida, J.A., Piskuła, M.K. \& Zieliński, H. (2015). Recent advances in development of gluten-free buckwheat products. Trends Food Sci. Tech., 44, 58-65. DOI: 10.1016/j.tifs.2015.02.013

15. Guang C. \& Philips R.D. (2009). Plant Food-Derived Angiotensin I Converting Enzyme Inhibitory Peptides. J. Agr. Food Chem., 57, 5113-5120. DOI: 10.1021/jf900494d

16. Hidalgo, A. \& Brandolini A. (2011). Heat damage of water biscuits from einkorn, durum and bread wheat flours. Food Chem., 128, 471-478. DOI: 10.1016/j.foodchem.2011.03.056 
17. Higasa, S., Fujihara, S., Hayashi, A., Kimoto, K. \& Aoyagi, Y. (2011). Distribution of a novel angiotensin I-converting enzyme inhibitory substance (2"-hydroxynicotianamine) in the flour, plant parts, and processed products of buckwheat. Food Chem., 125, 607-613. DOI: 10.1016/j.foodchem.2010.08.074

18. Iwaniak, A., Minkiewicz, P. \& Darewicz M. (2014). Food-originating ACE inhibitors, including antihypertensive peptides, as preventive food components in blood pressure reduction. Com. Rev. Food Sci. Food Safety, 13, 114-134. DOI: 10.1111/1541-4337.12051

19. Jakobek, L. (2015). Interactions of polyphenols with carbohydrates, lipids and proteins. Food Chem., 175(Supplement C), 556-567. DOI: 10.1016/j.foodchem.2014.12.013

20. Je, J.Y., Qian, Z.J., Byun, H.G. Kim, S.K. (2007). Purification and characterization of an antioxidant peptide obtained from tuna backbone protein by enzymatic hydrolysis. Process Biochem., 42, 840-846. DOI: $10.1016 /$ j.procbio.2007.02.006

21. Juan, M.Y., Wu, C.H. \& Chou, C.C. (2010). Fermentation with Bacillus spp. as a bioprocess to enhance anthocyanin content, the angiotensin converting enzyme inhibitory effect, and the reducing activity of black soybeans. Food Microbiol., 27, 918-923. DOI: 10.1016/j.fm.2010.05.009

22. Kawakami, A., Inbe, T., Kayahara, H. \& Horii, A. (1995). Preparations of enzymatic hydrolysates of buckwheat globulin and their angiotensin I converting enzyme inhibitory activities. Curr. Adv. Buckwheat Res., 2, 927-934.

23. Kim, S.K., Byun, H.G., Park, P.J. \& Shahidi, F. (2001). Angiotensin I converting enzyme inhibitory peptides purified from bovine skin gelatin hydrolysate. J. Agr. Food Chem., 49, 2992-2997. DOI: $10.1021 / \mathrm{jf} 001119 \mathrm{u}$

24. Kuba, M., Tana, C., Tawata, S. \& Yasuda, M. (2005). Production of angiotensin I-converting enzyme inhibitory peptides from soybean protein with Monascus purpureus acid proteinase. Process Biochem., 40, 2191-2196. DOI: 10.1016/j.procbio.2004.08.010

25. Kumar, R., Kumar, A., Sharma, R. \& Baruwa, A. (2010). Pharmacological review on natural ACE inhibitors. Der Pharmacia Lettre, 2(2), 273-293.

26. Lafarga, T., Gallagher, E., Bademunt, A., Bobo, G., Echeverria, G., Viñas, I. \& Aguiló-Aguayo, I. (2019). Physiochemical and nutritional characteristics, bioaccessibility and sensory acceptance of baked crackers containing broccoli co-products. Int. J. Food Sci. Technol., 54, 634-640. DOI: 10.1111/ijfs. 13908

27. Lacaille-Dubois, M.A., Franck, U. \& Wagner, H. (2001). Search for potential Angiotensin Converting Enzyme (ACE)-inhibitors from plants. Phytomedicine, 8, 47-52. DOI: 10.1078/0944-7113-00003

28. Li, Ch-H., Matsui, T., Matsumoto, K., Yamasaki, R. \& Kawasaki, T. (2002). Latent Production of Angiotensin I-Converting Enzyme Inhibitors from Buckwheat Protein. J. Peptide Sci., 8, 267-274. DOI: 10.1002/psc.387

29. Matsui, T., Li, C.H. \& Osajima, Y. (1999). Preparation and characterization novel bioactive peptides responsible for angiotensin I converting enzyme inhibition from wheat germ. J. Peptide Sci., 5, 289297. DOI: 10.1002/(SICI)1099-1387(199907)5:7<289::AID-PSC196>3.0.CO;2-6

30. Miguel, M., Contreras, M.M., Recio, I. \& Aleixandre, A. (2009). ACE inhibitory and antihypertensive properties of a bovine casein hydrolysate. Food Chem., 12, 211-214. DOI: 10.1016/j.foodchem.2008.05.041

31. Mojica, L., Chen, K. \& González de Mejia, E. (2015). Impact of Commercial Precooking of Common Bean (Phaseolus vulgaris) on the Generation of Peptides, After Pepsin-Pancreatin Hydrolysis, Capable to Inhibit Dipeptidyl Peptidase-IV. J. Food Sci., 80, 188-198. DOI: 10.1111/1750-3841.12726

32. Muller, M.R., Wolfrum, G., Stolz, P., Ehrmann, M.A. \& Vogel, R.F. (2001). Monitoring the growth of Lactobacillus species during a rye flour fermentation. Food Microbiol., 18(2), 217-227. DOI: 10.1006/fmic.2000.0394

33. Pan, M.-H., Lai, C.-S., Dushenkov, S. \& Ho, C.-T. (2009). Modulation of inflammatory genes by natural dietary bioactive compounds. J. Agr. Food Chem., 57, 4467-4477. DOI: 10.1021/jf900612n

34. Park, J.W., Lee, Y.J. \& Yoon, S. (2007). Total flavonoids and phenolics in fermented soy products and their effects on antioxidant activities determined by different assays. J. Korean Society Food Cul., 22, 353-358.

35. Pyo, Y.H. \& Lee, T.C. (2007). The potential antioxidant capacity and angiotensin I-converting enzyme inhibitory activity of Monascus-fermented soybean extracts: evaluation of Monascus-fermented 
soybean extracts as multifunctional food additives. J. Food Sci., 72, S218-S223. DOI: 10.1111/j.17503841.2007.00312.x

36. Ren, X., Ma, H., Mao, S. \& Zhou, H. (2014). Effects of sweeping frequency ultrasound treatment on enzymatic preparations of ACE-inhibitory peptides from zein. Eur. Food Res. Technol., 238, 435-442. DOI: $10.1007 / \mathrm{s} 00217-013-2118-3$

37. Rui, X., Wen, D., Li, W., Chen, X., Jiang, M. \& Dong, M. (2015). Enrichment of ACE inhibitory peptides in navy bean (Phaseolus vulgaris) using lactic acid bacteria. Food Function, 6, 622-629. DOI: $10.1039 / \mathrm{c} 4$ fo00730a

38. Sentandreu, M.Á. \& Toldrá, F. (2006). A rapid, simple and sensitive fluorescence method for the assay of angiotensin I converting enzyme. Food Chem., 97(3), 546-554. DOI: 10.1016/j.foodchem.2005.06.006

39. Spínola, V., Llorent-Martínez, E.J. \& Castilhoa, P.C. (2018). Antioxidant polyphenols of Madeira sorrel (Rumex maderensis): How do they survive to in vitro simulated gastrointestinal digestion? Food Chem., 259, 105-112. DOI: 10.1016/j.foodchem.2018.03.112

40. Torino, M.I., Limón, R.I., Martínez-Villaluenga, C., Mäkinen, S., Pihlanto, A., Vidal-Valverde, C. \& Frias, J. (2013). Antioxidant and antihypertensive properties of liquid and solid state fermented lentils. Food Chem., 136, 1030-1037. DOI: 10.1016/j.foodchem.2012.09.015

41. Tsai, H., Deng, H., Tsai, S. \& Hsu, Y. (2012). Bioactivity comparison of extracts from various parts of common and tartary buckwheats: evaluation of the antioxidant- and angiotensin converting enzyme inhibitory activities. Chem. Central J., 6, 78-82. DOI: 10.1186/1752-153X-6-78

42. Wang, C.; Tian, J.; Wang, Q. (2011). ACE inhibitory and antihypertensive properties of apricot almond meal hydrolysate. Eur. Food Res. Technol., 232, 549-556. DOI: 10.1007/s00217-010-1411-7

43. Wiczkowski, W., Szawara-Nowak, D., Sawicki, T., Mitrus, J., Kasprzykowski, Z. \& Horbowicz M. (2016). Profile of phenolic acids and antioxidant capacity in organs of common buckwheat sprout. Acta Alimentaria, 45, 250-257. DOI: 10.1556/066.2016.45.2.12

44. Wronkowska, M., Jeliński, T., Majkowska, A. \& Zieliński, H. (2018) Physical properties of buckwheat water biscuits formulated on fermented flours by selected lactic acid bacteria. Pol. J. Food Nutr. Sci., 68, 25-31. DOI: 10.1515/pjfns-2017-0027

45. Xiao, Y., Xing, G., Rui, X., Li, W., Chen, X., Jiang, M. \& Dong, M. (2015). Effect of solid-state fermentation with Cordyceps militaris $\mathrm{SN}-18$ on physicochemical and functional properties of chickpea (Cicer arietinum L.) flour. LWT - Food Sci. Technol., 63, 1317-1324. DOI: 10.1016/j.1wt.2015.04.046

46. Yao, F., Sun, C. \& Chang, S.K.C. (2012). Lentil polyphenol extract prevents angiotensin II-induced hypertension, vascular remodelling and perivascular fibrosis. Food Function, 3, 127-133.

47. Zielińska, D., Szawara-Nowak, D. \& Zieliński, H. (2013). Antioxidative and anti-glycation activity of buckwheat hull tea infusion. Int. J. Food Prop., 16(1), 228-239. DOI: 10.1080/10942912.2010.551308

48. Zieliński, H., Michalska, A., Amigo-Benavent, M., del Castillo, M.D. \& Piskuła M.K. (2009). Changes in protein quality and antioxidant properties of buckwheat seeds and groats induced by roasting. J. Agr. Food Chem., 57, 4771-4776. DOI: 10.1021/jf900313e

49. Zieliński, H., Ciesarová, Z., Kukurová, K., Zielińska, D., Szawara-Nowak, D., Starowicz, M. \& Wronkowska, M. (2017). Effect of fermented and unfermented buckwheat flour on functional properties of gluten-free muffins. J. Food Sci. Technol., 54(6), 1425-1432.

50. Zieliński, H., Szawara-Nowak, D., Bączek, N. \& Wronkowska, M. (2019). Effect of liquid-state fermentation on the antioxidant and functional properties of raw and roasted buckwheat flours. Food Chem., 271, 291-297. DOI: 10.1016/j.foodchem.2018.07.182 